\title{
Humans or Machines? Scientific Determinism within the Context of Yoruba Human Ontology
}

\author{
Oluwatoyin Adebola GBADAMOSI, PhD \\ University of Ibadan, \\ Ibadan, Nigeria \\ E-mail: tygbadamosi@gmail.com \\ Doi: https://doi.org/10.46222/pharosjot.1037
}

\begin{abstract}
Freewill has been a subject of intense study in the history of philosophy, this revolves around the debate that are humans free or are their actions determined? While there has been a lot of questions on the nature of human will, the search for answers remains relevant in contemporary studies as seen in the entrance of neuroscience to this quest. Neuroscience, in the study of the human will arrived at a conclusion based on empirical studies that freewill is an illusion because the human will is determined by cerebral activities. The discovery in the field of neuroscience therefore challenges the traditional belief about freewill and our beliefs that humans are in full control of their will. This submission indicated that human decisions for actions were initiated before humans became aware of them, that is, likening humans to machines, thereby creating a lacuna especially within the Yoruba religious and cultural contexts. This study therefore, interrogated the position of neuroscience on the human will by focusing on how scientific determinism can be viewed from the Yoruba worldview. Scientific determinism evident in the field of neuroscience was examined with a view to situating the findings of neuroscience on human will within the context of Yoruba human ontology.
\end{abstract}

Keywords: Freewill, Neuroscience, Yoruba Human Ontology, Scientific Determinism, Cognition.

\section{Introduction}

Advances in scientific studies create room for speculation on the nature of humanity, given the success of science in different areas of study. The entrance of cognitive neuroscience to the debate on freewill has renewed interest in the ancient debate and also changed the course of the debate from what applied in the past which revolves round the various variants of determinism such as theological, physical, psychological, and cultural determinism, to something new. The new debate, which is the science driven debate, revolves around the science of the brain and the submission that human beings do not have what is believed as freewill, with the implication that humans may be likened to mere machines. There are some instances where positions of scholars can be seen as mere threats to freewill as well as other cases where there is an outright denial of freewill premised on the findings in the field of neuroscience. However, like any other subject in philosophy, the position of neuroscience is not one that is universally shared. Philosophers, theologians, and even neuroscientists are of different opinions on the subject of freewill, based on the submission of neuroscience. This study is therefore poised to examine scientific determinism within the context of human ontology of the Yoruba, Southwest Nigeria. 


\section{Methodology}

This study adopted a modus of Experimental Philosophy, which is a relatively new methodology in philosophy as it employs experiments or empirical studies to unravel traditional issues in philosophy. An example of such traditional issues is the subject of freewill. Neuroscientists held the view that freewill is an illusion because the human will is determined by cerebral activities, making it imperative to use the methods of Experimental Philosophy. Experimentation featured greatly in this study because results of experiments of neuroscientists and psychologists were used to analyze the extant philosophical ideas on human will. By the use of Experimental Philosophy here, the subject of freewill was examined, using systematic empirical studies on the subject by situating it within the context of Yoruba religion and culture. Experimental Philosophy as used in this study adopts an interdisciplinary approach to the subject matter by viewing it through the lens of neuroscience, psychology, philosophy, religion and the culture of the Yoruba.

\section{Humans or Machines? Neuroscientific Arguments against Freewill}

Do we have freewill or are our actions beyond our control? This is a hoary question that philosophers and theologians have grappled with for years. Now, neuroscientists have joined the quest to answer this question, thereby creating another question, are we humans or machines? Neuroscience, while trying to solve the puzzle surrounding freewill, came to an interesting conclusion which threatens the established notion that humans are free. A major reason why neuroscience serves as a threat to this established notion is because the position of neuroscience is believed to be based on empirical evidence derived from various factual experiments. It is interesting to note that even neuroscientists themselves are of different opinions on the subject of freewill. Some are reluctant to admit that freewill does not exist, while some others make a subtle denial of the notion of freewill and still, others admit outrightly that freewill does not exist. A notable advocate of the latter notion is Sam Harris, who makes a very direct attack on the subject of freewill. In his book, Against Freewill, he makes a lot of cases in his denial of freewill. According to him, "freewill is an illusion; our wills are simply not of our own making. Thoughts and intentions emerge from background causes of which we are not aware and over which we have no conscious control. We do not have the freedom we think we have" . He asks also that: "how can we make sense of our lives, and hold people accountable for their choices, given the unconscious origin of our conscious mind?"2 These are serious questions because of the importance of accountability, which is necessary in any sane, normal human environment. Daniel Wegner also shares the position of Harris that freewill is an illusion: there is a very conspicuous and catchy statement which comprises the first words of Wegner's book "it usually seems that we consciously will our actions, but this is an illusion". ${ }^{3}$ Wegner believes that calling an illusion might be too strong but he posits that most prior understandings of human will may not fit into current scientific realities.

The argument of the neuroscientist is that the whole idea of freewill can be reduced to causal, bodily processes. This is not a new idea, but a-two-and-a-half century-old supposition. It was l'homme machine (man a machine), a philosophical manifesto by Julien Offray de La Metrie, that solved the problem of Cartesian dualism. La Metrie's manifesto was decisive for the future of modern science, 'science of the human'. This is relevant today for Verplaetse made efforts to prove that there is no freewill, and that everything a human being does can be traced back to

\footnotetext{
${ }^{1}$ S. Harris. (2012). Free Will. New York: Simon \& Schuster. 5

${ }^{2}$ S. Harris. (2012). Free Will, New York: Simon \& Schuster. 5-8

${ }^{3}$ D. Wegner. (2002). The Illusion of Consciousness. Cambridge: Bradford Books. 1-2
} 
strict causality. ${ }^{4}$ This causality is the crux of the argument against freewill, and these causal bodily processes originate outside of consciousness. This is the basis of the argument of the scholars that oppose freewill. If a person is unconscious of the processes and the origin of his/her intentions or actions, then how can such acts be regarded as free?

Bruce Hood also seems to be an advocate of the position of neuroscience which seems to suggest that freewill is an illusion. However, Hood presents a different meaning of the term illusion. According to him, although our daily experiences are so familiar, yet the brain science shows that this is an illusion. The term illusion as seen by Hood does not mean that it does not exist, but rather that 'it is not what it seems:' Hood agrees that understanding that the self or our will is not true is really quite difficult to admit, subsequently it may be one of the most difficult to accept since our will or self seems so convincing or real. But then, again, many aspects of our experiences are not what they seem. ${ }^{5}$ The point of the argument here is that history reveals to us that a number of cultural and religious beliefs have been disproved by modern findings and such beliefs are no longer valid, such as the shape of the earth, the erroneous belief of the sun circling the earth, the age of the earth and other similar notions. If these notions are debunked as a result of research and modern findings, what is the guarantee that the hitherto held notion that humans have freewill could also not be disproved as neuroscience seems to suggest?

On another similar note, Heidi Ravven argues that it is not obvious that human beings have freewill as we like to believe, in the way that we have hands and feet, instead freewill is a cultural assumption, and it is an assumption that turns out to be false. Ravven argues further that freewill is a cultural assumption which has its root in Western culture. He believes that the culture that support freewill is hinged on the assumed moral nature of humans --- that 'everyone' knows we have freewill. This notion, Ravven argues, is false. ${ }^{6}$ He believes that the belief in freewill is a western cultural idea which he believes has its roots also in Christianity that is not universally shared. Ravven believes also that the notion of freewill is based on a theological story whose religious origin and meaning people are often unaware of and which some even reject explicitly. He traces the belief in freewill to early Latin Christianity which was widely disseminated through authoritative thinkers who outlawed contrary views and later became engrained in our laws, institutions and practices and passed down from one generation to another. ${ }^{7}$ Similarly, Nicholas Vale also uses historical evidence to argue against freewill. He believes that although evidences demonstrating that we do not have freewill are accumulating in the sciences like neuroscience and psychology, in philosophy, however, history shows arguments against freewill. The logical arguments against freewill have been understood since the times of the Greeks. ${ }^{8}$ Verplaetse also made reference to neuroscience as well as the whole argument against freewill long before the advent of neuroscience.

Harris posits categorically that, a person's intention to act in a way or to do a particular thing or action and not something else does not begin in his /her consciousness, but he posts that, it appears in unconsciousness. Harris made use of the findings of Benjamin Libet and findings from more recent research to argue against freewill. "Direct recordings from the cortex showed that the

\footnotetext{
${ }^{4}$ J. De Vos (Ed.) (2016) Neuroscience and Critique: Exploring the Limits of the Neurological Turn. New York: Routledge. 14

${ }^{5}$ B. Hood. (2012). The Self Illusion: How the Social Brain Creates identity. Oxford: Oxford University Press ix ${ }^{6} \mathrm{H}$. Ravven. (2013) The Self Beyond itself: An Alternative History of Ethics, the New Brain Sciences and the Myth of Free will. New York: The New Press. (Np: Ebook)

${ }^{7}$ H. Ravven. (2013) The Self Beyond itself: An Alternative History of Ethics, the New Brain Sciences and the Myth of Free will. New York: The New Press. (Np: Ebook)

${ }^{8}$ N. Vale. (2012) The Newer Testament: The Bible of No Free Will. U.S.A: The Master Teachers. 531
} 
activity of merely 256 neurons were sufficient to predict with $80 \%$ accuracy a person's decision to move 700 milliseconds before he became aware of it... these findings are difficult to reconcile with the sense that we are conscious authors of our actions". ${ }^{9}$ Similarly, whether by accident, disease or debauchery, studies in brain science shows that if the brain is damaged, the person is different. Also, taking certain drugs can alter the functioning of the brain and the behavior of a person. So, who 'we are' depends on our brains even though we are not just our brains in isolation.

Another argument that tilts in favour of the position of neuroscience as it threatens freewill is from the perspective of the relevance of the debate for moral responsibility within the context of criminal law. The point here is that since the existence of freewill is questioned, and retributive punishment on the other hand requires freedom of the will, there is a need then to revise our justification for punishment or eliminate punishment altogether. The kind of responsibility suggested here is known as desert-based morality, and it may not be pragmatic because blame is its corollary and the application of sanction my not be practical because emphasis is on the person and not the action. ${ }^{10}$ In Living without Free will, Derek Pereboom argues that imagining a life without the idea of freewill and morality would not be as destructive as many people believe. ${ }^{11}$ This idea of a need to re-think our ideas of morality and responsibility is quite relevant in Nigeria in cases where the punitive measures are directly proportional or related to the persons and not to the actions. The 'small' thief, who steals a mobile phone or a goat for example is most times usually punished whereas the 'big' thief such as politicians or government officials who steal huge sums of money, most times, gets away. The major point of this argument is that the findings of neuroscience suggest a need to revise the existing punitive practices and examine the justification for punishments. However, the call for the elimination of punishment altogether is another issue entirely because of the practicality of this suggestion in any human society especially as it relates to human values.

Sam Harris, as vocal as he is on the subject of the absence of human freewill, makes some valid salient assertions on human will as it concerns human values. He claims that the more knowledge and understanding we have on the workings of the human brain, the better positioned we are in providing right or wrong answers to questions related to human values. Harris in his phenomenal book 'The Moral Landscape: How Science can determine Human Values' has a unique goal of beginning a discourse on how morality may be truly understood in scientific terms which is within another context, outside of ethics or philosophy. ${ }^{12}$ This means that in reality, what we do is often as a result of other factors around us and the state of our mind, not really "the will". For example, a clergyman in a cassock will most likely not fight with a bus conductor no matter the level of aggravation. This is not because he cannot exchange blows with him, but because certain factors will determine his actions not to fight. His behavior is most likely dependent on the cassock he is wearing, the societal or religious expectations from him (as a priest, that he is conscious of), and the state of his mind at that particular time.

Bruce Waller also makes a strong case which may make allow one to wonder if humans are not becoming machines by suggesting a world void of moral responsibility. In his book, Against Moral Responsibility, he cites many examples in which practices of moral responsibility are counterproductive from a humanitarian or practical standpoint. ${ }^{13}$ The position of Waller is valid and practical to a large extent because it is true that oftentimes, 'morality', draws us away from the

\footnotetext{
${ }^{9}$ S. Harris. (2012) Free Will, New York: Simon \& Schuster. 8-9.p

${ }^{10}$ N. Vincent (Eds.) (2011). Moral Responsibility: Beyond Freewill and Determinism. 141

${ }^{11}$ G. Caruso. (Ed.) (2013).Exploring the Illusion of Freewill and Moral Responsibility. Lanhan: Lexington Books. 7

12 S. Harris. (2011). The Moral Landscape: How Science Can Determine Human Values. New York: Free Press.1-2

${ }^{13}$ G. Caruso (Ed.). (2013) Exploring the Illusion of Freewill and Moral Responsibility. Lanham: Lexington Books. 7
} 
hidden factors responsible for people's actions. We usually place a lot of emphasis on the 'actions' at the expense of the factors that have influenced the acts. When a person is involved in an act, morality makes us quick to judge the act leaving little or no room for the various factors such as genetics, up-bringing, social status, education, religion, race and other salient and important factors.

Sam Harris, in another work titled Free Will, makes some valid assertions similar to those of Waller. He says:

Without freewill, sinners and criminals would be nothing more than poorly calibrated clock-work and any conception of justice that emphasized punishing them (rather than deterring, rehabilitating or merely curtailing them) would appear incongruous. ${ }^{14}$

Harris goes further to relate a very graphic tale of a heinous crime in which two career criminals Steven Hayes and Joshua Komisarjersky in July 23, 2007, killed a family in a most brutal way. Harris makes some important points, that whether criminals like these two men mentioned above can be judged for the factors that led to their acting the way they did and not mere because of what they did. According to Harris:

As sickening as I find their behavior, I have to admit that if I were to trade places with one of these men, atom for atom, I would be him. If I had been in the shoes of one of these criminals and had his genes and life experiences and an identical brain or soul in an identical state-I (Harris) would have acted exactly as he did. ${ }^{15}$ (Harris, 2015:4-5)

Smit asks also, in corroboration with the position of Harris; Did you choose your genetic composition? Did you choose your looks, talents or weaknesses, your baritone or sonorous voice, or your peculiar character traits? A substantive part of these factors was determined genetically. ${ }^{16}$ Similarly, Igor Alexander asks some interesting questions: what is it in our brain that determines our decisions? How free is my desire or my volition? What are the factors that determine which choice I will make? Is what I actually do pre-determined in some way? What we naturally think about freewill is a product of the culture in which we live. Freewill is an integrated part of our consciousness, and it is therefore a matter for brain science and through axioms, a matter for which we might try to identify mechanisms that can be said to possess it. Aleksander claims also that it was the famous discovery of Benjamin Libet that led Harvard psychologist Dan Wegner to argue that determining what we want is not based on conscious brain activity at all, but on some unconscious occurrence which both determines what we want and how we get it. Wegner argues that what we feel about having caused things to happen by willing it is false for conscious will is an illusion. ${ }^{17}$

This means, most times thoughts flick through our minds. Often times we do not originate these thoughts, they just come "on their own" and most times, we act on these thoughts impulsively. It must be noted that although we cannot originate certain thoughts on our own, we also have the power, sometimes to make them go away or retain them, or to act or not to act on them.

\footnotetext{
${ }^{14}$ S. Harris. (2012). Free Will. New York: Simon \& Schuster .4

${ }^{15}$ S. Harris. (2012). Free Will. New York: Simon \& Schuster. 4-5

${ }^{16}$ P. Smite. (2014). Enlightenment for Lazy People. Retrieved 24 ${ }^{\text {th }}$ November, 2015 from http://www.paulsmit.nu

${ }^{17}$ I. Aleksander. (2013). The World in My Mind, My Mind in the World: Key Mechanisms of Consciousness in people, Animals and Machines. Digital Version: Andrews UK Limited retrieved from www.andrewsuk.com $8^{\text {th }}$ April, 2016
} 
Astonishing though the hypothesis may be, according to Stephen Pinker "the evidence is now overwhelming that it is true. Many cause-and-effect linkages have a physical event on one side and a mental event on the other."18 Pinker narrates the possibility of altering who a person is when certain electrical, chemical or biological changes occur in the brain. Such a person behaves differently as a result of the change that has taken place. Thus, the minutest details of brain activities are now accessible through the new technologies, "such as: functional magnetic resonance imaging, magneto encephalography, positron emission tomography and electroencephalography". ${ }^{19}$ Tiny details of different activities such as thought, perception emotion and other activities produce different signals which can be read as a result of the new technologies. ${ }^{20}$

To explain this fact, Pinker gives an astonishing example of the brain under surgery:

When a surgeon takes a surgical knife and cuts the corpus callosum, (a part of the brain which joins the two cerebral hemispheres), the mind is split in two and in some sense the body is inhabited by two selves. Under the microscope, the tissues of the brain show a breath-taking degree of complexity-perhaps a hundred trillion synapses-that is fully commensurate with the breath-taking complexity of human thought and experience. ${ }^{21}$ (Pinker, 1999:np)

This fact shows that the brain is not just an ordinary organ in the body; it has a lot of dominance on what is understood as the "self'. Another example that supports this fact is the issue of insanity, a person that is sick in the brain loses his/her grasp on his/her personality, he/she becomes a different person and would be seen doing what he/she might not have done in a normal state.

In spite of the various positions of scholars that argue directly or indirectly against freewill on the basis of the position of neuroscience, it is imperative to discuss the famous 1983 work of Benjamin Libet. This is necessary because Libet is responsible for this revolutionary thinking on the subject of freewill. However, it is worthy of note that Libet also might have been influenced by the works of others because he made references to the works of Deecke, Grozinger \& Kornhuber (1976), Vaughn \& Coster (1966) and Kornhuber \& Deecke (1965). He quoted all these works while trying to explain the origin of 'RP' (readiness potential) and the bases of further research in this area. However, he ended up becoming popular with the whole idea of employing neuroscience to solve the problems of freewill. Libet believes that the discovery of 'RP' opened up the new possibilities for analysing freewill through experiments which is what experimental philosophy is all about.

In the legendary article of Libet which contributed immensely to the revolution in the subject of freewill, he presents a number of findings which served as the bases of subsequent studies and the premise of the arguments of several scholars including some of the ones discussed earlier. These later studies were probably carried out to debunk his findings or corroborate his positions; it however turned out that these studies became the bases of the acceptance of his views and they made his work very popular. In this famous article of Libet, his argument is quite straight-

\footnotetext{
${ }^{18}$ S.Pinker. April 20 and 21, (1999).The Blank Slate, the Noble Savage, and the Ghost in the Machine: The Tanner Lectures on Human Values Delivered at Yale University.

${ }^{19}$ S.Pinker. April 20 and 21, (1999).The Blank Slate, the Noble Savage, and the Ghost in the Machine: The Tanner Lectures on Human Values Delivered at Yale University.

${ }^{20}$ S.Pinker. April 20 and 21, (1999.)The Blank Slate, the Noble Savage, and the Ghost in the Machine: The Tanner Lectures on Human Values Delivered at Yale University.

${ }^{21}$ S.Pinker. April 20 and 21, (1999).The Blank Slate, the Noble Savage, and the Ghost in the Machine: The Tanner Lectures on Human Values Delivered at Yale University.
} 
forward, if humans are conscious of their intentions to act in a particular way, then, the experience of initiation of such activities should begin before or should start at the same time brain (cerebral) activities related to such activities begin. This process has been faulted by various experiments which show that what is understood as volitional acts occur after electro physiological processes called readiness potential- RPs. ${ }^{22}$

The meaning of this argument of Libet is this; if a conscious intent or decision to act initiates voluntary acts, then personal experience of initiating this act must occur before brain activities or at least occur at the same time. Another interpretation is this; our understanding of factors related to freewill is that it is the person, the mind or the soul or whatsoever we understand as the 'real self' that should pass 'orders' of will, intention or decision to do a particular thing to the brain, which would then send the message to the related part of the body, for example the leg, which would perform the action; say move to a place. However, these brain experiments have disrupted this flow of events, the brain is now the first point of action, the argument of Libet is that for our understanding of freewill to be valid, the brain activities for an action should not begin before the 'real self' is conscious of that act or least both brain activities and personal consciousness should coincide, but not the former before the later.

As daunting as this barrage of evidence from neuroscience suggesting that human actions are not really free which reduces humanity to the level of machines, there are obvious implications for accepting their conclusions in the real world outside of the laboratories of the neuroscientist, psychologists or the world of the philosophers. In a society like that of the Yoruba, this scientific understanding of human will can only make sense by understanding the ontology of the word human, which begins with an understanding of the race.

\section{Background Study of the Yoruba}

The origin of the Yorùbá is mostly traced to Oduduwa, who is believed to be the progenitor of the people. The Yorùbá people predominate in south western Nigeria and are one of the major ethnic groups in the country. ${ }^{23}$ Nigeria is situated in the West African sub-region and it is the most populous black nation on earth with an estimated population of over 140 million people. ${ }^{24}$ The Yorùbá people are one of the largest tribes in Africa, with about thirty million individuals throughout the region of Africa. ${ }^{25}$ To answer the question, Who are the Yorùbá, this is a deep and complex task which goes beyond mere identification through a name. This is because several factors contribute to make the Yorùbá who they are. As Olusanya writes,

There is probably no other African people who have commanded as much attention of scholars of all disciplines as much as the Yorùbá. Their physical environment, history, mythology, language, artistic traditions, thought systems, social and political institutions, religion, moral and aesthetic values, economic and medical systems in Africa and the diaspora have been and continuing to be of great attention to scholars and researchers. ${ }^{26}$ (Odusanya, 1983:26)

\footnotetext{
${ }^{22}$ B. Libet .(1985). Unconscious Cerebral Initiative and the Role of Conscious Will in Voluntary Action. The Behavioural and Brain Sciences. Vol. 8, U.S.A. 529-566

${ }^{23}$ T. Aderibigbe . (2009). Faith and Fertility; Attitudes towards Reproductive Practice in Different Religions from Ancient times to modern times. Blyth, T.\& Landaur, R. (Eds.). London: Jessica Kingsley Publishers. 180

${ }^{24}$ NPC (2006) Retrieved July 14, 2014 from www.nigeria.unfpa.org/youngpeople.html

${ }^{25}$ N.A Retrieved (July 11, 2014) from www.awonifa.com/yoruba-folklore/76Yoruba-medicine

${ }^{26}$ G. Odusanya (Ed.) (1983). Studies in Yoruba History and Culture. Ibadan: Ibadan University Press. 26
} 
The Yorùbá are regarded also as one of the most advanced communities in West Africa. Though the question of the origin of the Yorùbá is still a debatable subject, a fact remains clear; the Yorùbá are homogeneous in origin. Their language, in spite of its many dialects provides the main evidence of a common origin and cultural heritage. This language spoken by many people within and outside the shores of Nigeria is known as the Yorùbá language.

\section{The Yoruba Human Ontology}

The freewill problem premised on the position of neuroscience revolves round the issue of 'selfawareness of causes of actions', are we actually aware of the causes of our actions? Are we actually conscious of processes that initiated what we call voluntary behavior? If indeed we are not free as neuroscience seems to suggest, then our actions are beyond our control. Who takes responsibility for our actions if indeed they are beyond our control? In the light of these germane questions, one cannot discard the proven discovery of science because of the speculative but established beliefs influenced by our religious, cultural or ethical ideas. Although, to a Yorùbá, these beliefs are not just mere assumptions, they are still stern beliefs taken very seriously which shapes the behaviors of the Yorùbá. Is it possible then to accept the conclusion of neuroscience which threatens freewill and jeopardize the so-called assumptions of the Yorùbá on human personality? This is an important question that has grave implications at a personal level and at a communal level. It is therefore necessary to have a clear understanding of human personality among the Yorùbá in order to understand the implications of a scientific finding on human will. The focal point of the discourse at this point is the Yorùbá meaning of a "man" èniyàn. This is not necessarily a gender description of the male sex, but a generic expression of a human being.

A human being, according to Yorùbá belief system, is not just a mere physical being whose existence is dictated alone by physical factors present in this world. According to Adebola Akintola, at the stage of divine creation of man, there was a free intercourse between God and the divinities, which predicated the creation of man in heaven and his subsequent establishment on earth. ${ }^{27}$ It is necessary to note also that religion is dominant in the whole life of the Yorùbá. Thus, the Yoruba conception of a human being is essentially religious. A human being is viewed from the conception of her/his relation to the gods; her/his life in the existing state of living in this world and human destiny in the after-life. All these are brought into the orbit of religious conceptions. ${ }^{28}$ In order to understand the unique concept of human personality held by the Yorùbá, there are some important factors that should be taken into consideration. These are the beliefs which influence what constitute a human person and a number of different factors which affect his/her existence or the quality of life on earth will also be examined. These are the belief in the physical and non-physical nature of a human being, man's preparation in heaven before coming to the earth, the roles of God's powerful agents in the world, the concepts of Orì, Énikeji, man's guardian angel or double, death and immortality of the soul of man. An understanding of these beliefs is necessary in order to understand what to do with the conclusion of neuroscience which threatens freewill in the Yorùbá view on human personality.

\section{The Physical and Non-Physical Nature of a Human Being}

The Yorùbá like many other peoples of the world are of the belief that the human nature is both material and immaterial. The Yoruba belief is that a human being has the material body which is used to live and interact in the physical world. They also hold the notion that there is also the non-

\footnotetext{
${ }^{27}$ A. Akintola. (1999). Yoruba Ethics and Metaphysics. Ogbomoso: Valour Publishing Ventures Limited.53

${ }^{28}$ J. Lucas. (1948). The Religion of the Yorubas. Lagos: C.M.S Bookshop. 245
} 
material body which interacts in the metaphysical sense. ${ }^{29}$ According to Adebowale Akintola, the Yorùbá, taking their cue from Ộrúnmìlà, the fountain source of all wisdom, believe that man is not just a biological phenomenon resulting from the reproductive mating of a male and female. He is a created being, a product of the divine and creative will of Olódùmarè, the Supreme-being. Not only the first man and the first woman (labeled Adam and Eve in Christian mythology) were created beings; according to Ifá mythology, every child born into this world, till this present time, has been individually created first (his spirit-personality having been created in heaven) only chooses to move down to the earth for a temporary sojourn through the human regenerative process. This also implies that a man's sojourn on earth is merely a continuation of his earlier activities in heaven. ${ }^{30}$ This belief that man is not only a biological phenomenon but also a spiritual phenomenon whose sojourn on earth being a continuation of what began in heaven is only possible if a human being has two natures; one physical and the other non-physical. Bolaji Idowu has written extensively on the subject of the dual nature of man held by the Yorùbá ${ }^{31}$ to which several other scholars make reference to internationally and locally.

On a similar note, Akintola holds also that the Yorùbá believe that man is made up of two parts -- viz the physical part created in a clay mould and the spiritual part which is the very eternal essence of God, Olódùmarè Himself. This belief is substantiated thus, Olódùmarè sent Ikú (death or morbidity divinity) to procure clay with which man's body was to be moulded. Sàngó (alias Àjàlá) moulded man's head. To complete the body mould, Òrìsà-ńlá (God's own representative on earth) was assigned to give human shape to the mould, that is, shape of the mouth, nose, ears and general human figuring. Finally, Olódùmarè, ordered all the divinities in attendance during the creation ritual to close their eyes whilst He breathed His own essence, which is spirit, into the nostrils of the moulded human body. This essence automatically makes man to become a living man... a fully created being. It is in connection with the story that Ọrúnmilà is depicted as a divinity that knows it all. Òrúnmilà did not close his eyes fully; and so, with partially opened eyes, saw Olódùmarè as He was breathing His spirit into man. Ọrúnmìlà alone saw Olódùmarè as He was sharing His essence with carnal or earthly man--- hence, the saying, "Ọrúnmilà, ẹlẹri İpín (Òrúnmìlà, witness to Olódùmarè's sharing His spirit with humankind. ${ }^{32}$ Although in some cases, the ipin here is understood as allotment or portion which as to do with destiny. Bolaji Idowu holds this view of ipin which is slightly different from Akintola's view because Idowu calls a person' destiny İpin-Ori- the lot of Ori's (Orí here does not only means physical head, but has a lot do with destiny) portion or lot which he believes is usually abbreviated as ipi $n^{33}$. Regardless of whichever meaning one wants to subscribe to, some facts remain valid in the two views, İpin has to do with a person's share or allotment, which could be a man's share of the life of Olódùmarè, or a man's share of the èmí- spirit of Olódùmarè or a person's allotment of his destiny. The main issue derived from these beliefs is that the Yorùbá believe in the intangible aspect of the life of a person which is the person's share or allotment.

Idowu makes a clear distinction between èmí spirit and èémí- breath. Ėmí is causative of breath and the 'breather', that which breathes in man. This belief influences the saying regarding someone who is just dead; èmí rẹ ti bọ́- his èmí has slipped off, èémi ti tán nínú rè - there is no more breath in him. Idowu says further that to the Yorùbá, there is more to man than just body and spirit. ${ }^{34}$ Similarly, Ayo Salami, goes further to say that the Ėmí is housed by the Orí and that

\footnotetext{
${ }^{29}$ J. Lucas, (1948). The Religion of the Yorubas. Lagos: C.M.S Bookshop. 245

${ }^{30}$ A. Akintola, (1999). Yoruba Ethics and Metaphysics. Ogbomoso: Valour Publishing Ventures Limited.64

${ }^{31}$ E. Idowu (1996). Olodumare: God in Yoruba Belief (Revised and Enlarged Ed.) Lagos: Longman. 179

${ }^{32}$ A. Akintola, (1999). Yoruba Ethics and Metaphysics. Ogbomoso: Valour Publishing Ventures Limited.66

${ }^{33}$ E. Idowu (1996). Olodumare: God in Yoruba Belief (Revised and Enlarged Ed.) Lagos: Longman. 181

${ }^{34}$ E. Idowu (1996). Olodumare: God in Yoruba Belief (Revised and Enlarged Ed.) Lagos: Longman. 179
} 
Ėmí is not limited in time, energy and space. Hence, it could travel between many ends without losing time. It is the same Emi that would return to heaven when the man dies. Ėmí cannot perish at death, since it came from Olódùmarè, it has to return to Him at the death of a person. Ėmí is spiritual and cannot be seen, it is intangible and can move from one place to another. ${ }^{35}$ This belief of the Yorùbá is also held by Christians, who believe that man is a spirit and that the spirit move from one place to another and that no one can understand the ways of the spirit except him that is of the spirit. ${ }^{36}$ If the spirit can move from one place to the other, then it is in order to believe that the spirit can attain different bodies. Adetunji holds this belief as a characteristic of Ėmi among the Yorùbá. According to her, in Yorùbá witchcraft belief, it is held that the Emi of a witch incarnates in physical form in animals such as a bird. And that if such a bird is caught and killed, the witch automatically dies. ${ }^{37}$ This means the Ėmi can move from one place to the other without its house, the human body but will need to assume another physical body such as animals like birds or cats as seen in the case of witchcraft.

The general belief is that the Ėmi of people only leave their bodies at death. Is it then only the Émí of witches that can move from one body to another while still living? Adetunji answers this question in a way, she points out that the human body needs Ėmi to 'enliven' it, answering the question- Can Ėmi exists without the body? She says, the human body is an important factor for the existence of Emí. Ėmí is only man's Émí when it is in man, outside the body it is not capable of independent existence and also by the same token, the body without Ėmí is just cadaver. ${ }^{38}$ There is therefore a symbiotic relationship between the body (Ara) and the Spirit Émí, existence is only possible when these two composite parts of a human being are functioning together. Oladipo calls this relationship a "relationship that is made up of certain inter-locking elements, these elements only come active when they are infused with the active life-giving spark, Ėmí. Summarily, neither Ėmí nor Ara, taken separately, each by itself can be said to be the human person. ${ }^{39}$ The Ėmi is the important part of the dual nature of the human being that cannot be seen while the physical part that houses the Ėmí is known as Ara or body which comprises of several parts.

Ara is the Yorùbá conception of a human body, it is the composite element of a man that can be seen, felt and that which moves from place to place. It is the means by which a person carries out his/her activities in this world. It is also the major form of identifying a person, having peculiar features of colour, height, weight, builds or frames which makes the process of identification possible. This involves also a broad classification of gender which could be either male or female identified by the genitals. Regardless of the gender, there are some general body parts which make up the Ara of a person. It is interesting to note that to the Yorùbá, the different parts of Ara are not just physical organs of the body, they have different metaphysical significances. The human head is known as Orí, to the Yorùbá, Orí is not just a mere physical organ that comes in different shapes and sizes; it is a symbol of deep metaphysical functions. Okàn- heart is another bodily part which has both physical and spiritual significance. According to Lucas, the word Ọàn can be used in two different senses; firstly, the material heart and secondly, as a distinct entity which he calls the "heart-soul" or the intelligent faculty responsible for human thoughts and

\footnotetext{
${ }^{35}$ A. Salami. (2008). Yoruba Theology \& Tradition: The Man and the Society. Lagos: NIDD Limited. 29

${ }^{36}$ Ecclesiastes 11:5; I Corinthians 2:11

${ }^{37}$ H. Adetunji .(2001) Ori and Moral Responsibility in Yoruba Belief. PhD. Thesis. Dept. of Religious Studies. University of Ibadan 55

${ }^{38}$ H. Adetunji (2001) Ori and Moral Responsibility in Yoruba Belief. PhD. Thesis. Dept. of Religious Studies. University of Ibadan 55

${ }^{39}$ O. Oladipo, (1992). The Yoruba Conception of a Person: An Analytico - Philosophical Study. International Studies in Philosophy. 132
} 
actions. The second sense is more important to the Yorùbá because it forms part of the immaterial, imperishable and imperishable part of man. Lucas says further that "the Okàn is believed to exist before a man's birth which may be the Okàn of an ancestor or of any deceased person. It may also be the Okàn of an abiku, that is "one that is born to die" and thereby causing the child into which it has entered to die young." ${ }^{40}$ Every part of the human body is important to the Yorùbá both in the material and spiritual sense because to them a man is seen as having both physical and non-physical nature.

Although the Yoruba cannot account for their religious or cultural views empirically, they are valid because they serve a pragmatic purpose to the people concerned. However, taking the findings of neuroscience literally as some philosophers do and maintaining that freewill is an illusion will create a lot of problems because of its controversial conclusion. This is because neuroscience offers only a materialistic understanding of man as it discusses the neurons and the cerebral processes, whereas to a Yoruba, a Human being is more than these. Neuroscience fails to acknowledge the metaphysical view of man held in Yorùbá religion. It is true that the cerebral processes neuroscience offers its understanding is lacking within the religious or cultural view of man, it is however not a holistic view.

The Yorùbá race is not an individualistic one that neuroscience tends to assume for all. The Yorùbá do not believe in an individualistic existence that is why they say, Á dá se ní hun ọmọ, Ibà kií hun omo. Solitary acts are doomed, but when a person honours- (elders and ancestors) such acts are blessed. They also say- Ojú Méeji ló bí ọmọ, igba ènìyàn ló ń wò ó- Even though it is one person that gives birth to a child, more than one person raise the child. Thus, to the Yoruba, a person's brain cannot decide for her/him because of the non-individualistic awareness the people have.

\section{Conclusion}

History reveals to us that religion or culture often gives credence to scientific positions eventually even in spite of the initial resistance to new findings which are at odds with its position. The submission of neuroscience which is used as the premise to suggest that freewill does not exist has serious implications in any civilized society. 'Not having freewill' is indeed a severe threat to the established notion of responsibility firmly established in the Yorùbá religious and cultural beliefs.

The freewill problem premised on the position of neuroscience revolves round the issue of consciousness, which is also understood as 'self-awareness of causes of actions', making one to wonder that are we actually aware of the causes of our actions? Or are we actually conscious of processes that initiated what we call voluntary behavior? In spite of all the empirically verified truth presented by neuroscience, there are some serious implications for the sustenance of this discovery in the field of neuroscience on human freewill. If indeed we are not free, then our actions are beyond our control. If our actions are beyond our control, then what are the religious, moral and cultural implications of our actions? Who takes responsibility for our actions if indeed they are beyond our control? What neuroscience seems to say is that there is the absence of consciousness in the decision-making process. Absence of consciousness is then used as the basis to conclude that there is no freewill. This study prefers to interpret the position of

\footnotetext{
${ }^{40}$ J. Lucas.(1948). The Religion of the Yorubas. Lagos: C.M.S Bookshop. 247
} 
neuroscience to mean we are neither in 'full control' of the processes of our decision making nor are we truly autonomous as we believe, thus, it is pragmatic to conclude that freewill is compatible with determinism. This position does not rob humans of their freedom entirely because they need to take responsibility for their actions even though there are reasons to doubt if we are truly humans or machines as neuroscience submits. However, in any human society like that of the Yoruba, humans are not robots because in reality, people face the consequences of their actions. Imagining a man to be a machine is an absurdity because a machine cannot fit into the ontology of man as believed among the people. To a Yoruba, a human being is more metaphysical than physical and the human will is a product of complex systems which cannot be reduced to only systematic empirically verifiable means.

\section{References}

Aderibigbe T. (2009). in Faith and Fertility; Attitudes towards Reproductive Practice in Different Religions from Ancient times to modern times. Blyth, T. \& Landaur, R. (Eds.), London: Jessica Kingsley Publishers.

Adetunji, H. (2001). Ori and Moral Responsibility in Yoruba Belief. PhD. Thesis. Dept. of Religious Studies. University of Ibadan.

Akintola, A. (1999). Yoruba Ethics and Metaphysics, Ogbomoso: Valour Publishing Ventures Limited.

Aleksander, I. (2013). The World in My Mind, My Mind in the World: Key Mechanisms of Consciousness in people, Animals and Machines. Digital Version: Andrews UK Limited. [Available online at www.andrewsuk.com] Retrieved $8^{\text {th }}$ April, 2016.

Caruso, G. (Ed.) (2013). Exploring the Illusion of Freewill and Moral Responsibility, Lanhan: Lexington Books.

De Vos, J. (Ed.) (2016). Neuroscience and Critique: Exploring the Limits of the Neurological Turn, New York: Routledge.

Harris, S. (2011). The Moral Landscape: How Science Can Determine Human Values, New York: Free Press.

Harris, S. (2012). Free Will, New York: Simon \& Schuster.

Hood, B. (2012). The Self Illusion: How the Social Brain Creates identity, Oxford: Oxford University Press.

Idowu, E. (1996). Olodumare: God in Yoruba Belief(Revised and Enlarged Ed.) Lagos: Longman.

Libet, B. (1985). Unconscious Cerebral Initiative and the Role of Conscious Will in Voluntary

Action. The Behavioural and Brain Sciences. Vol. 8, U.S.A.

Lucas, J. (1948). The Religion of the Yorubas. Lagos: C.M.S Bookshop. [Available online at www.awonifa.com/yoruba-folklore/76Yoruba-medicine] Retrieved July 11, 2014. 
NPC (2006). Retrieved July 14, 2014 from www.nigeria.unfpa.org/youngpeople.html

Odusanya, G. (Ed.) (1983). Studies in Yoruba History and Culture, Ibadan: Ibadan University Press.

Oladipo, O. (1992). The Yoruba Conception of a Person: An Analytico - Philosophical Study, International Studies in Philosophy, 24(3), 15-24.

Pinker, S. (April 20 and 21, 1999). The Blank Slate, the Noble Savage, and the Ghost in the Machine, The Tanner Lectures on Human Values: Yale University.

Ravven, H. (2013). The Self Beyond itself: An Alternative History of Ethics, the New Brain Sciences and the Myth of Free will, New York: The New Press. (Np: Ebook)

Salami, A. (2008). Yoruba Theology \& Tradition: The Man and the Society, Lagos: NIDD Limited.

Smite, P. (2014). Enlightenment for Lazy People. [Available online at http://www.paulsmit.nu] Retrieved 24th November, 2015.

Vale, N. (2012). The Newer Testament: The Bible of No Free Will, USA: The Master Teachers.

Vincent, N. (Eds.) (2011). Moral Responsibility: Beyond Freewill and Determinism, Dordrecht: Springer (August 17, 2011).

Wegner, D. (2002). The Illusion of Consciousness, Cambridge: Bradford Books. 